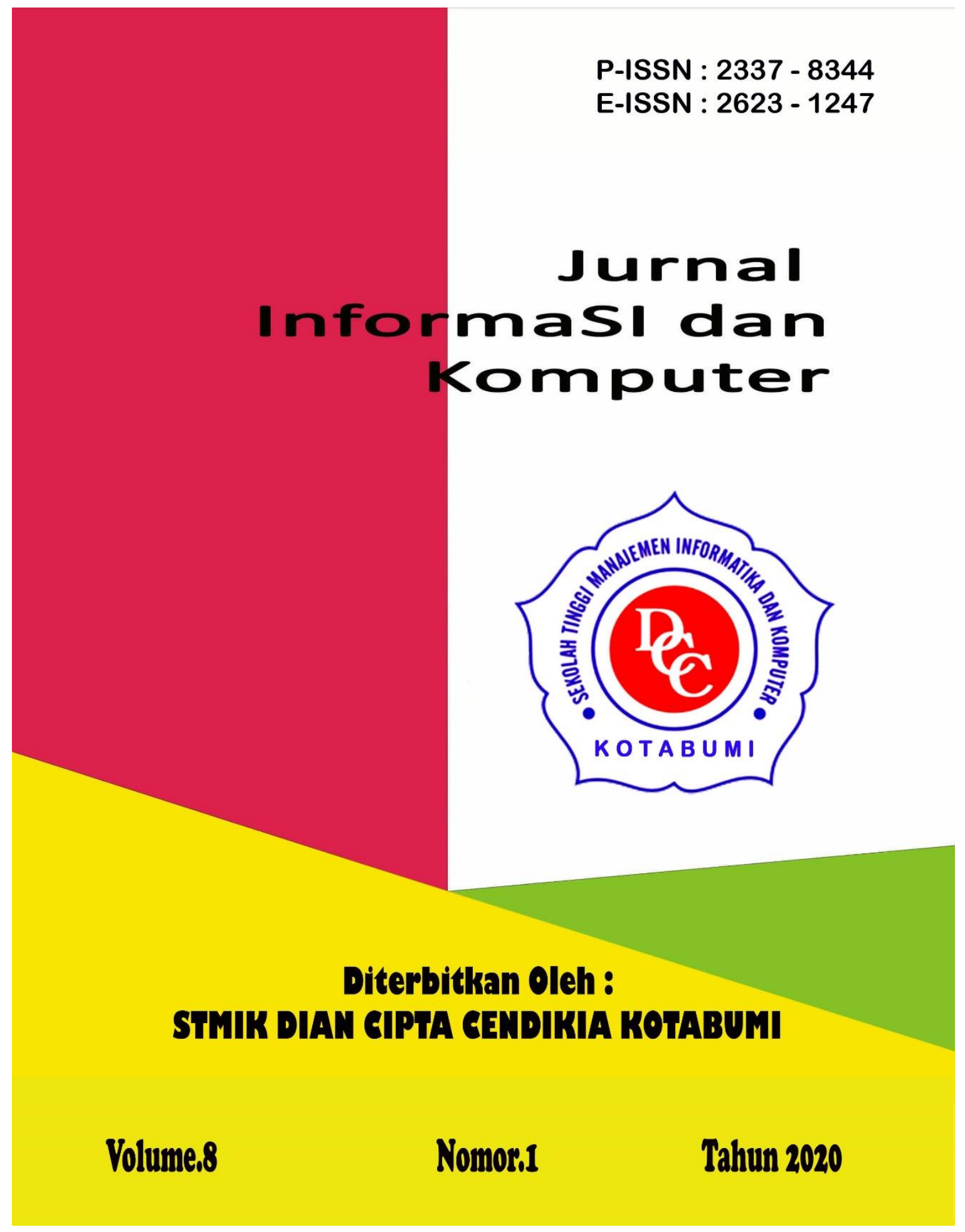




\section{Penerbit:}

STMIK DIAN CIPTA CENDIKIA KOTABUMI

Bekerjasama dengan LPPM STMIK DCC Kotabumi

Hak atas naskah/tulisan tetap berada pada penulis, isi diluar tanggung jawab

Penerbit dan Dewan Penyunting

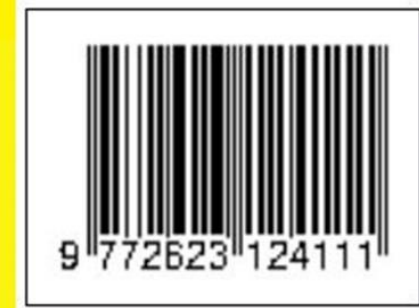




\section{PENGANTAR REDAKSI}

Puji syukur dipanjatkan kehadirat Tuhan Yang Maha Esa, atas karunia dan limpahan rahmatNYA jualah Jurnal Informatika dan komputer (InfoKom) STMIK Dian Cipta Cendikia Kotabumi ini dapat terwujud.Jurnal Informatika dan Komputer (InfoKom) yang terbit dua (2) kali dalam setahun ini merupakan suatu wadah untuk penyebar luasan hasil-hasil penelitian, studi pustaka, karya ilmiah yangberkaitan dengan Informatika dan Komputer khususnya bagi dosen-dosen STMIK Dian Cipta Cendikia Kotabumi serta umumnya para cendikiawan, praktisi, peneliti ilmu Informatika dan Komputer.

Harapan, dengan diterbitkannya Jurnal Informatika dan Komputer (InfoKom) ini sebagai salah satu bentuk sumbangan pemikiran dalam pengembangan ilmu informatika dan komputer yang berkaitan dengan kajian-kajian di bidang tekhnologi Informatik, Komunikasi Data dan Jaringan Komputer, perancangan dan Rekayasa Perangkat Lunak, serta ilmu-ilmu yang terkait dengan bidang Informatika dan Komputer lainnya.

Berkenaan dengan harapan tersebut, kepada para peneliti, dosen dan praktisi yang memiliki hasil-hasil penelitian, kajian pustaka, karya ilmiah dalam bidang tersebut diatas, dengan bangga redaksi Jurnal Informatika dan Komputer (JIK) menerima naskah ringkasan untuk dimuat pada jurnal Informatika dan Komputer (InfoKom) STMIK Dian Cipta Cendikia Kotabumi dengan berpedoman pada penulisan naskah jurnal sebagaimana dilampirkan pada halaman belakang (Bagian kulit dalam) buku jurnal ini.

Mutu dari suatu jurnal ilmiah tidak hanya ditentukan oleh para pengelolanya saja, tetapi para penulis dan pembaca jualah yang mempunyai peranan besar dalam meningkatkan mutu jurnal Informatika dan Komputer ini. Merujuk pada realita ini kamu sangat mengharapkan peran aktif dari peneliti untuk bersama-sama menjaga dan memelihara keberlangsungan dari jurnal Informatika dan Komputer STMIK Dian Cipta Cendikia Kotabumi ini. Yang juga tidak kalah pentingnya dari partisipasi tersebut diatas, adalah saran dan kritik yang membangun dari pembaca yang budiman agar kiranya dapat disampaikan langsung kepada redaksi JIK. Saran dan kritik yang membangun akan dijadikan masukan dan pertimbangan yang sangat berarti guna peningkatan mutu dan kualitas Jurnal Informatika dan Komputer STMIK Dian Cipta Cendikia Kotabumi.

Tak lupa diucapkan terima kasih yang tak terhingga atas perhatian dan kerjasama dari semua pihak yang tak dapat disebutkan satu persatu hingga dapat diterbitkan nya Jurnal Informatika dan Komputer (InfoKom) STMIK Dian Cipta Cendikia Kotabumi. Semoga apa yang telah diperbuat untuk kebaikan akan menjadi amal ibadah, amin.

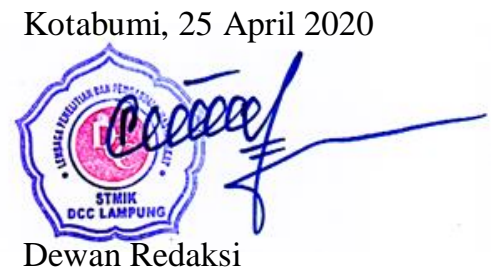




\section{JURNAL INFORMASI DAN KOMPUTER}

Volume 8 Nomor 1 April 2020

Jurnal Informasi dan Komputer merupakan Sarana informasi ilmu pengetahuan, Tekhnologi dan Komunikasi yang berupa hasil penelitian, tulisan ilmiah, Ataupun studi pustaka. Jurnal ini terbit dua kali setahun pada bulan April dan Oktober. Berisi hasil penelitian ilmiah di bidang informatika yang bertujuan untuk menghubungkan adanya kesenjangan antar kemajuan teknologi dan hasil penelitian. Jurnal ini di terbitkan pertama kali pada tahun 2013.

Penanggung Jawab:

Ketua STMIK Dian Cipta Cendikia

Kotabumi

\section{Pembina:}

Ketua STMIK Dian Cipta Cendikia

Kotabumi

Ketua Lembaga Penelitian STMIK Dian

Cipta Cendikia Kotabumi

\section{Pimpinan Redaksi}

Dwi Marisa Efendi,.S.Kom.,M.Ti

\section{Redaksi pelaksana}

Rustam,.S.Kom,.M.Ti (STMIK Dian

Cipta Cendikia Kotabumi)

Nurmayanti M.Kom (STMIK Dian

Cipta Cendikia Kotabumi)

Sukatmi,.S.Kom., M.Kom (AMIK DCC

Bandar Lampung)

Sampurna Dadi Riskiono,M.Kom

(Universitas Teknokrat Indonesia)

Ifo Wahyu

Pratama,S.Kom.,M.Ti(AMIK MASTER

Lampung)

\section{Mitra Bestari}

Merri Parida.,M.Kom (STMIK Dian

Cipta Cendikia Kotabumi)

Amarudin,S.Kom.,M.Eng (Universitas

Teknokrat Indonesia)

Didi Susianto.,S.T.,M.Kom (AMIK

DCC Bandar Lampung)

Alhibarsyah.,S.T.,M.Kom (Stmik Tunas

Bangsa Bandar Lampung)

Kemal Farouq Mauladi

.,S.Kom.,M.Kom (Universitas Islam

Lamongan)

Agus Setiawan S.Pd.,M.Eng

(Universitas Muhammadiyah

Lamongan)

Penerbit : STMIK Dian Cipta Cendikia Kotabumi Bekerja Sama Dengan LPPM STMIK Dian Cipta Cendikia Kotabumi.

\section{Alamat Redaksi/Penerbit:}

Jl. Negara No. 3 Candimas Kotabumi

Lampung Utara

No Telpon/Fax 072423003

Email : 1ppm-stmik@dcc.ac.id 


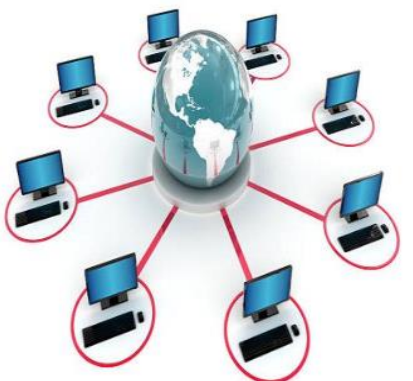 \\ JURNAL INFORMASI DAN KOMPUTER VOL. 8 NO. 1 THN. 2020}

\section{DAFTAR ISI}

\section{Halaman}

Sistem Pendukung Keputusan Penentuan Lahan Kopi Terbaik Dengan Metode

Ahp (Analytic Hierarchy Process)

Sidik Rahmatullah, Rendy Abdurahman (AMIKKOM Jogja,

STMIK Dian Cipta Cendikia Kotabumi)

Rancang Bangun Sistem Informasi Pada Program Pembangunan Pemberdayaan

Masyarakat Desa( P3md ) Berbasis Web Mobile

Ferly Ardhy, Firmansyah, Sidik Rahmatullah,(IIB Darma Jaya Bandar Lampung

STMIK Dian Cipta Cendikia Kotabumi, AMIKKOM Jogja)

Sistem Informasi Pengolahan Data Alumni Sekolah Menengah Atas (Sma)

Merri Parida, Nindiya Ova Rahmawati (AMIKKOM Jogja,

STMIK Dian Cipta Cendikia Kotabumi)

SISTEM INFORMASI GEOGRAFIS PUSKESMAS BESERTA SARANA

DAN PRASARANA BERBASIS WEB MOBILE

Nurmayanti, Windy Dwi Bahari (AMIKOM Jogja,

STMIK Dian Cipta Cendikia Kotabumi)

Rancang Bangun Sistem Informasi Konseling Untuk Sekolah Menengah Kejuruan

(Smk) Berbasis Website

Aliy Hafiz1, Galih Rakasiwi, Ifo Wahyu Pratama, Agus Komarudin,

Bambang Suparapto, Fathurrahman Kurniawan Ikhsan

(AMIK Dian Cipta Cendikia Bandar Lampung,

Universitas Nahdhatul Ulama Lampung, AMIK Dian Cipta Cendikia Pringsewu,

Universitas Mitra Indonesia, Lampung) .....

Sistem Pendukung Keputusan Pemilihan Driver Terbaik Menggunakan Metode

Weight Product (Wp)

Dina Lorenza, Pitrawati (STMIK Dian Cipta Cendikia Kotabumi

AMIK Dian Cipta Cendikia)

Rancang Bangun Sistem Informasi Pembayaran Mahasiswa

Darsin(Universitas Megou pak Tulang Bawang)

Sistem Informasi Geografis Bengkel Motor Honda Resmi Bandar Lampung

Sukatmi, Nuraini (AMIK Dian Cipta Cendikia Bandar Lampung).....

Sistem Pakar Diagnosa Penyakit Kulit Wajah Dengan Metode

Certainty Factor Pada Klinik Skin Rachel

Dwi Marisa Efendi, Putri Yulita Sari (IIB Darmajaya Bandar Lampung,

STMIK Dian Cipta Cendikia Kotabumi)..... 
Sistem Informasi Monitoring Siswa Pada Mts Al-Islamiah Bunut Kabupaten Pesawaran Yuli Syafitri ${ }^{2}$, Reni Astika ${ }^{1}$, Septian Hernando ${ }^{3}$

Aplikasi Kamus Bahasa Jepang Berbasis Mobile Android

Rustam $^{2}$ A Yanda Febry Pangestu ${ }^{2}$ Sistem Informasi, Teknologi Komputer ${ }^{1}$, IIB Darmajaya

Bandar Lampung ${ }^{2}$ STMIK Dian Cipta Cendikia Kotabumi 


\title{
SISTEM PENDUKUNG KEPUTUSAN PENENTUAN LAHAN KOPI TERBAIK DENGAN METODE AHP (ANALYTIC HIERARCHY PROCESS)
}

\author{
Sidik Rahmatullah ${ }^{1}$ Rendy Abdurahman ${ }^{2}$ \\ Teknologi Komputer ${ }^{1}$, Sistem Informasi ${ }^{2}$ \\ STMIK Dian Cipta Cendikia Kotabumi \\ Jl.Negara Nomor 03 Candimas Kotabumi Lampung Utara \\ E-mail: sidik@dcc.ac.id, Rendyabdurahman@gmail.com
}

\begin{abstract}
ABSTRAK
Sebagian besar produksi kopi di Indonesia merupakan komoditas perkebunan yang dijual ke pasar dunia. Perkembangan penggunaan sumber daya lahan sampai saat ini belum memberikan kontribusi yang nyata dalam meningkatkan produksi kopi. Hal ini dipengaruhi oleh kondisi lahan yang bervariasi berdasarkan letak georafis pada Desa Gunung Gijul sehingga dibutuhkan sebuah sistem pendukung keputusan yang dapat membantu dalam meningkatkan produksi kopi di Desa Gunung Gijul, Lampung Utara yang dapat membantu masyarakat dalam menentukan lahan kopi terbaik. Pada Sistem Pendukung Keputusan Penentuan Lahan Kopi Terbaik menggunakan Metode Analytic Hierarchy Process ini menggunakan metode pengembangan sistem Waterfall dan untuk bahasa pemrograman menggunkan Borland Delphi 7 , dengan database menggunakan Microsoft Acces. Sistem Pendukung Keputusan Penentuan Lahan Kopi Terbaik menggunakan Metode Analytic Hierarchy Process ini meliputi data Lahan, penilaian AHP serta pelaporan. Pendekatan yang digunakan untuk mendukung Sistem Pendukung Keputusan Penentuan Lahan Kopi Terbaik adalah Metode Analytic Hierarchy Process. Sistem ini bertujuan untuk memudahkan masyarakat Desa Gunung Gijul dalam penentuan lahan kopi terbaik sehingga dapat meningkatkan jumlah produksi kopi. Sistem ini menghasilkan Penentuan lahan kopi terbaik dengan beberapa kriteria yang digunakan unsur organik, mineral tanah, sumber air, kemiringan lahan, dan tanaman sebelumnya.
\end{abstract}

Kata kunci : Sistem Pendukung Keputusan, Analytic Hierarchy Process, Waterfall, Borland Delphi 7, Desa Gunung Gijul

\begin{abstract}
Most of coffee production in Indonesia is plantation commodities which are sold to the world market. The development of the use of land resources to date has not contributed significantly to increasing coffee production. This is influenced by varying land conditions based on the geographical location of Gunung Gijul Village, so a decision support system is needed that can help in increasing coffee production in Gunung Gijul Village, North Lampung, which can help the community in determining the best coffee land. In the Decision Support System for Deciding the Best Coffee Land using the Analytic Hierarchy Process Method, using the Waterfall system development method and for the programming language using Borland Delphi 7, with a database using Microsoft Access. The Decision Support System for Deciding the Best Coffee Land Using the Analytic Hierarchy Process Method includes data Land, AHP assessment and reporting. The approach used to support the Decision Support System for Deciding the Best Coffee Land is the Analytic Hierarchy Process Method. This system aims to facilitate the people of Gunung Gijul Village in determining the best coffee land so that it can increase the amount of coffee production. This system produces Determination of the best coffee land with several criteria used by organic elements, soil minerals, water sources, slope of land, and previous crops.
\end{abstract}

Keyword : Decision Support System, Analytic Hierarchy Process Waterfall, Borland Delphi 7, Mountain Village Gijul, 


\section{PENDAhuluan}

Kopi merupakan salah satu komoditas unggulan dalam subsector perkebunan di Indonesia karena memiliki peluang pasar yang baik di dalam negeri maupun luar negeri. Sebagian besar produksi kopi di Indonesia merupakan komoditas perkebunan yang dijual ke pasar dunia. Menurut International Coffee Organization (ICO) konsumsi kopi meningkat dari tahun ke tahun sehingga peningkatan produksi kopi di Indonesia memiliki peluang besar untuk mengekspor kopi ke negara-negara pengonsumsi kopi utama dunia seperti Uni Eropa, Amerika Serikat dan Jepang. [1]

Perkembangan penggunaan sumber daya lahan sampai saat ini belum memberikan kontribusi yang nyata dalam meningkatkan produksi kopi. Hal ini dipengaruhi oleh kondisi lahan yang bervariasi berdasarkan letak georafis dan topografinya, yang masing-masing mempengaruhi produktifitas hasil kopi. Diperlukan perencanaan yang matang dalam mengambil keputusan terutama jenis tanaman kopi yang akan ditanam. Perencanaan dan pengambilan keputusan harus dilandasi oleh data dan informasi yang akurat tentang kondisi lahan.[2]

Gunung Gijul adalah desa yang berada di kecamatan Abung Tengah, Kabupaten Lampung Utara, dengan geografis pegunungan dan mayoritas masyarakat bekerja sebagai petani kopi. Namun dengan seiringnya waktu produktifitas kopi di gunung gijul semakin menurun dan perlunya strategi untuk meningkatkan produktifitas kopi, oleh karena itu semua faktor yang mempengaruhi pembangunan pertanian yang berkelanjutan, baik itu faktor pendukung maupun faktor pembatas harus dipikirkan sejak awal mulai dari penentuan lahan terbaik untuk penanaman kopi yang dituangkan dalam sebuah aplikasi yang dapat menjadi salah satu solusi strategi untuk meningkatkan produksi kopi di Desa Gunung Gijul.

Namun demikian dengan kondisi lahan yang terbatas dan kemampuan lahan tidak merata, maka pengembangan pertanian kopi yang berkelanjutan harus mempertimbangkan daya dukung lingkungan. Sedangkan faktor pembatas yang sering ditemui adalah kurangnya informasi dan data yang akurat tentang kondisi sumber daya alam, dimana data dan informasi merupakan instrumen yang sangat penting dalam perencanaan pembangunan disektor pertanian kopi sehingga dibutuhkan sebuah sistem pendukung keputusan yang dapat membantu dalam meningkatkan produksi kopi di Desa Gunung Gijul, Lampung Utara.

Menurut Rahman (2011:27), Sistem Pendukung Keputusan (SPK) atau Decision Support System (DSS) adalah sebuah sistem untuk mendukung para pengambil keputusan Manajerial dalam situasi keputusan semi terstruktur. Sistem Pendukung Keputusan atau DSS dimaksud untuk menjadi alat bantu bagi para pengambil keputusan untuk memperluas kemampuan mereka,namun tidak untuk menggantikan penilaian mereka.[3]

SPK bertujuan untuk menyediakan informasi, membimbing, memberikan prediksi serta mengarahkan kepada pengguna informasi agar dapat melakukan pengambilan keputusan dengan lebih baik. [3].

Konsep Sistem Pendukung Keputusan pertama kali diperkenalkan pada awal tahun 1970-1n oleh Michael S. Scoot Morton dengan istilah Management Decision System (Sprague, 1982). Konsep sistem pendukung keputusan ditandai dengan sistem interaktif berbasis komputer yang membantu pengambilan keputusan memanfaatkan data dan model untuk menyelesaikan masalah-masalah yang tidak terstruktur. [4].

Menurut Munthe (2016:35), AHP merupakan suatu model pendukung keputusan yang dikembangkan oleh Thomas L. Saaty. AHP merupakan metode untuk membuat urutan alternatif yang bertujuan untuk memilih yang terbaik pada saat pengambilan keputusan. Dalam AHP adakalanya timbul masalah keputusan yang dirasakan dan diamati perlu diambil secepatnya tetapi variasinya rumit sehingga datanya tidak mungkin dapat dicatat secara numerik. [6].

Menurut Rahardjo (2012) Kopi merupakan salah satu jenis tanaman perkebunan yang sudah lama dibudidayakan dan memiliki nilai ekonomis yang lumayan tinggi. Kopi berasal dari Afrika, yaitu daerah pegunungan di Etopia. Namun, kopi sendiri baru dikenal oleh masyarakat dunia setelah tanaman tersebut dikembangkan di luar daerah asalnya, yaitu Yaman di bagian selatan Arab Sejarah mencatat bahwa penemuan kopi sebagai minuman berkhasiat dan berenergi. Pertama kali 
ditemukan oleh Bangsa Etiopia di benua Afrika sekitar 3000 tahun (1000 SM) yang lalu. Kopi kemudian terus berkembang hingga saat ini menjadi salah satu minuman paling populer di dunia yang dikonsumsi oleh berbagai kalangan masyarakat. Indonesia sendiri telah mampu memproduksi lebih dari 400 ribu ton kopi per tahunnya. Di samping rasa dan aromanya yang menarik, kopi juga dapat menurunkan risiko terkena penyakit kanker, diabetes, batu empedu, dan berbagai penyakit jantung. (Rahardjo,2012). [4]

Menurut Presman (2015:49), model waterfall merupakan model klasik yang bersifat sistematis, berurutan dalam membangun software, Kelima tahapan itu tersusun dari atas ke bawah, diantaranya Analysis, Design, Coding, Testing, Maintenance. Setiap tahap harus diselesaikan terlebih dahulu secara penuh sebelum diteruskan ke tahap berikutnya untuk menghindari terjadinya pengulangan tahapan.

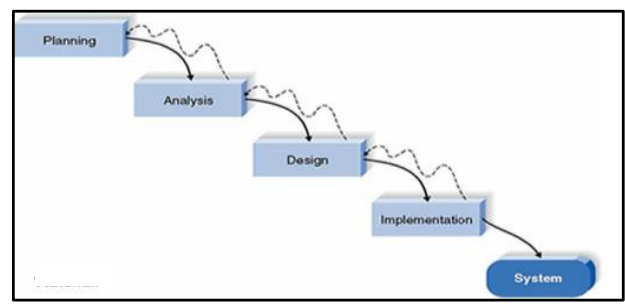

Gambar 1. Metode Waterfall

\section{METODE PENELITIAN}

\subsection{Teknik Pengumpulan Data}

\section{a. Wawancara}

Interview atau wawancara merupakan metode perzunipulan data yang menghendaki komunikasi langsung antara peneliti dengan subyek atau responden.

\section{b. Dokumentasi}

Metode dokumentasi berarti cara mengumpulkan data dengan mencatat data-data yang sudah ada. Maka dalam penelitian ini, dokumen atau catatan-catatan digunakan sebagai sumber untuk memperoleh data penerima bedah rumah

\section{c. Observasi}

Observasi (pengamatan) adalah alat pengumpulan data yang dilakukan dengan cara mengamati dan mencatat secara sitematik gejala-gejala yang diselidiki. Dalam metode ini dilakukan penelitian secara langsung dalam memperoleh data dari lapangan.

\section{d. Literalur}

Pada bagian ini akan difokuskan pada pencarian referensi relevan yang berkaitan dengan permasalahan yang sedang di teliti oleh penulis. Hal ini dilakukan agar peneliti mampu meningkatkan pemahaman dan pengetahuan teori tentang permasalahan yang sedang diteliti.

\subsection{Metode Pendukung Keputusan}

\section{a. Kriteria AHP}

Pada metode ini kriteria dan sub kriteria ditentukan dari Sumber Petugas Lapangan Pertanian Dinas Pertanian Kabupaten Lampung Utara.

Tabel 1 Kriteria AHP

\begin{tabular}{|c|c|c|c|}
\hline No & Kriteria & Sub Kriteria & Nilai \\
\hline \multirow[t]{3}{*}{1} & \multirow[t]{3}{*}{ Insur Organik } & $\geq 40$ & 3 \\
\hline & & $30-40$ & 2 \\
\hline & & $\leq 30$ & 1 \\
\hline \multirow[t]{3}{*}{2} & \multirow[t]{3}{*}{ Mineral Tanah } & $\geq 40$ & 3 \\
\hline & & $30-40$ & 2 \\
\hline & & $\leq 30$ & 1 \\
\hline \multirow[t]{3}{*}{3} & \multirow[t]{3}{*}{ Sumber Air } & Sungai & 3 \\
\hline & & Irigasi & 2 \\
\hline & & Sumur & 1 \\
\hline \multirow[t]{3}{*}{4} & \multirow[t]{3}{*}{ Kemiringan Lahan } & $\leq 20^{\circ}$ & 3 \\
\hline & & $20^{\circ}-30^{\circ}$ & 2 \\
\hline & & $\geq 30^{\circ}$ & 1 \\
\hline \multirow[t]{3}{*}{5} & \multirow{3}{*}{$\begin{array}{l}\text { Tanaman } \\
\text { Sebelumnya }\end{array}$} & Cengkeh/Lada/Kopi & 3 \\
\hline & & Karet/Coklat/Jati & 2 \\
\hline & & Kelapa/Pala & 1 \\
\hline
\end{tabular}

\section{b. Hirarki AHP}

Bagan AHP merupakan sebuah alur tingkatan hirarki Sebagai berikut :

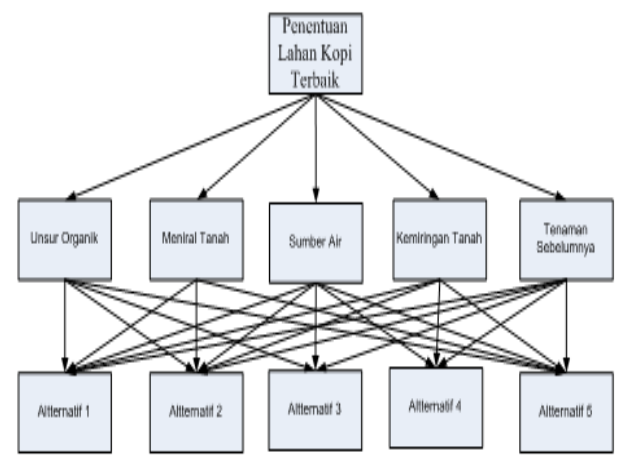

Gambar 2 Hirarki AHP

c. Penilaian Perbandingan Berpasangan 
Digunakan untuk menjadi acuan dalam menentukan matriks Berpasangan:

Tabel 2 Skala Penilaian Perbandingan Berpasangan

\begin{tabular}{|c|c|c|}
\hline Nilai & Definisi & Penjelasan \\
\hline 1 & Kedua elemen sama pentingnya & $\begin{array}{l}\text { Dua elemen mempunyai penganuh yang } \\
\text { sama besar terhadap tujuan }\end{array}$ \\
\hline 3 & $\begin{array}{l}\text { Elemen yang satu sedilitlebih } \\
\text { penting dari pada elemen yang } \\
\text { lain. }\end{array}$ & $\begin{array}{l}\text { Pengalaman dan penilaian sedikit } \\
\text { menyokong satu elemen dibandingkan } \\
\text { elemen lainnya. }\end{array}$ \\
\hline 5 & $\begin{array}{l}\text { Elemen yang satul lebihpenting } \\
\text { dari pada elemen yang lain }\end{array}$ & $\begin{array}{l}\text { Pengalaman dan perilaian sangat kuat } \\
\text { menyokong satu elemen dibandingkan } \\
\text { elemen lainnya. }\end{array}$ \\
\hline 7 & $\begin{array}{l}\text { Satu elemen jelas lebih mutlak } \\
\text { penting daripada elemen lainnya }\end{array}$ & $\begin{array}{l}\text { Satu elemen yang kuat disokong dan } \\
\text { dominant terlihat dalam praktek. }\end{array}$ \\
\hline 9 & $\begin{array}{l}\text { Satu elemen mutlak penting dari } \\
\text { pada elemen yang lain }\end{array}$ & $\begin{array}{l}\text { Bukti yang mendukung elemen yang satu } \\
\text { terhadap elemen yang lain memiliki } \\
\text { tingkat penegasan tertinggi }\end{array}$ \\
\hline $2,4,6,8$ & $\begin{array}{l}\text { Nillai-nilai antara dua nilai } \\
\text { pertimbangan yang berdekatan }\end{array}$ & $\begin{array}{l}\text { Nillai ini diberikan bila ada dua } \\
\text { kompromi di antara dua pilihan. }\end{array}$ \\
\hline Kebalikan & $\begin{array}{l}\text { jilka untuk aktifitas Imendapat s } \\
\text { maka jmempunya nilai kebalik }\end{array}$ & $\begin{array}{l}\text { u angka dibanding dengan aktivitas } j \text {, } \\
\text { nya dibanding dengan } \mathrm{i}\end{array}$ \\
\hline
\end{tabular}

d. Matrik Perbandingan Kriteria

Setelah memasukan data memperoleh hasil dibagi dari setiap kolom menggunakan matrik berpasangan dan kemudian dijumlahkan.

Tabel 3. Perbandingan Kriteria

\begin{tabular}{|c|c|c|c|c|c|}
\hline & $\mathrm{C} 1$ & $\mathrm{C} 2$ & $\mathrm{C} 3$ & $\mathrm{C} 4$ & $\mathrm{C} 5$ \\
\hline $\mathrm{C} 1$ & 1 & 2 & 3 & 5 & 3 \\
\hline $\mathrm{C} 2$ & $1 / 2$ & 1 & 2 & 2 & 3 \\
\hline $\mathrm{C} 3$ & $1 / 3$ & $1 / 2$ & 1 & 1 & 3 \\
\hline $\mathrm{C} 4$ & $1 / 5$ & $1 / 2$ & $1 / 1$ & 1 & 3 \\
\hline
\end{tabular}

Tabel 4 Hasil Jumlah dari Matriks Perbandinagan Kriteria

\begin{tabular}{|l|l|l|l|l|l|} 
& $\mathrm{C} 1$ & $\mathrm{C} 2$ & $\mathrm{C} 3$ & $\mathrm{C} 4$ & $\mathrm{C} 5$ \\
\hline $\mathrm{C} 1$ & 1,0000 & 2,0000 & 3,0000 & 5,0000 & 3,0000 \\
\hline $\mathrm{C} 2$ & 0,5000 & 1,0000 & 2,0000 & 2,0000 & 3,0000 \\
\hline $\mathrm{C} 3$ & 0,3333 & 0,5000 & 1,0000 & 1,0000 & 3,0000 \\
\hline C4 & 0,2000 & 0,5000 & 1,0000 & 1,0000 & 3,0000 \\
\hline C5 & 0,3333 & 0,3333 & 0,3333 & 0,3333 & 1,0000 \\
\hline Jumlah & 2,3667 & 4,3333 & 7,3333 & 9,3333 & 13,0000 \\
\hline
\end{tabular}

e. Normalisasi Matrik Perbandingan nilai dari setiap kolom dibagi nilai hasil jumlah kolom:

$$
\bar{a}_{j k}=\frac{a_{j k}}{\sum_{l=1}^{m} a_{l k}}
$$

Membagi setiap nilai dari kolom dengan hasil penjumlahan kolom untuk memperoleh normalisasi matriks dapat dilihat pada tabel berikut.

Tabel 5. Normalisasi Matrik Perbandingan

\begin{tabular}{|c|c|c|c|c|c|}
\hline & $\mathrm{C} 1$ & $\mathrm{C} 2$ & $\mathrm{C} 3$ & $\mathrm{C} 4$ & $\mathrm{C} 5$ \\
\hline $\mathrm{C} 1$ & 0,4225 & 0,4615 & 0,4091 & 0,5357 & 0,2308 \\
\hline C2 & 0,2113 & 0,2308 & 0,2727 & 0,2143 & 0,2308 \\
\hline C3 & 0,1408 & 0,1154 & 0,1364 & 0,1071 & 0,2308 \\
\hline C4 & 0,0845 & 0,1154 & 0,1364 & 0,1071 & 0,2308 \\
\hline C5 & 0,1408 & 0,0769 & 0,0455 & 0,0357 & 0,0769 \\
\hline
\end{tabular}

\section{f. Nilai Konsisten}

Memeriksa konsistensi hierarki rasio konsistensi (CI/IR)

1). Bobot Sintesis

Menghitung bobot sintesis dengan cara menjumlahkan tiap kolom.

$\sum$ kolom $=\mathrm{k} 1+\mathrm{k} 2+\mathrm{k} 3+\mathrm{k} 4+\mathrm{k} 5$

$\sum \begin{gathered}\mathrm{K} 1=0,4225+0,4615+0,4091+0,5357 \\ +0,2308=2,0596\end{gathered}$

$\sum \mathrm{K} 2=0,2113+0,2308+0,2727+0,2143$

2). Nilai Eigen

Cara mengalikan tiap kolom matriks perbandingan berpasangan pada baris yang sama, lalu dipangkatkan dengan seperjumlah kriteria.

$$
\begin{array}{r}
\lambda \mathrm{i}=(\mathrm{k} 1 \times \mathrm{k} 2 \times \mathrm{k} 3 \times \mathrm{k} 4 \times \mathrm{k} 5)^{\frac{1}{5}} \\
\lambda 1=(0,4225 \times 0,4615 \times 0,4091 \times 0,5357 \\
\times 0,2308)^{\frac{1}{5}}=2,2138 \\
\lambda 2=(0,2113 \times 0,2308 \times 0,2727 \times 0,2143 \\
\times 0,2308)^{\frac{1}{5}}=1,2253
\end{array}
$$

3). Bobot Prioritas

Menghitung bobot prioritas tiap kriteria dengan cara nilai eigen.

Tabel 6. Bobot Prioritas

\begin{tabular}{|l|c|c|c|c|c|c|c|c|}
\hline & $\mathrm{Cl}$ & $\mathrm{C} 2$ & $\mathrm{C} 3$ & $\mathrm{C4}$ & $\mathrm{C5}$ & $\begin{array}{c}\text { Bobot } \\
\text { Sintesis }\end{array}$ & $\begin{array}{c}\text { Niliai } \\
\text { Eigen }\end{array}$ & $\begin{array}{c}\text { Bobot } \\
\text { Prionitas }\end{array}$ \\
\hline $\mathrm{Cl}$ & 0,4225 & 0,4615 & 0,4091 & 0,3357 & 0,2308 & 2,0596 & 2,2138 & 0,4119 \\
\hline $\mathrm{C} 2$ & 0,2113 & 0,2308 & 0,2727 & 0,2143 & 0,2308 & 1,1598 & 1,2253 & 0,2320 \\
\hline $\mathrm{C} 3$ & 0,1408 & 0,1154 & 0,1364 & 0,1071 & 0,2308 & 0,7305 & 0,7597 & 0,1461 \\
\hline $\mathrm{C} 4$ & 0,0845 & 0,1154 & 0,1364 & 0,1071 & 0,2308 & 0,6742 & 0,7048 & 0,1348 \\
\hline $\mathrm{C} 5$ & 0,1408 & 0,0769 & 0,0455 & 0,0357 & 0,0769 & 0,3759 & 0,3834 & 0,0752 \\
\hline
\end{tabular}

$$
\begin{array}{ll}
\text { CI } & :(5,2370-5) /(5-1) \quad: 0,0593 \\
\text { CR } & : 0,0593 / 1,1200=\mathbf{0 , 0 5 2 9}<0,1
\end{array}
$$

\section{HASIL DAN PEMBAHASAN}

\subsection{Menu Utama}


Menu Utama adalah merupakan menu yang mengendalikan keseluruhan form. Untuk menjalankan menu utama, maka ikuti langkahangkah berikut: Setelah menu password benar maka akan tampil menu utama. Menu utama akan tampil seperti gambar 3 dibawah ini

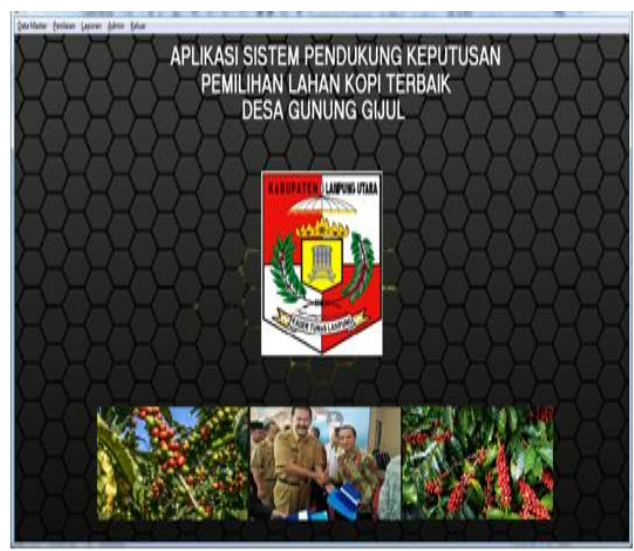

Gambar 3 Menu Halaman Utama

\subsection{Menu Data Lahan}

Untuk menjalankan sub menu Data Master ini, terlebih dahulu pemakai masuk kedalam menu utama program lalu pada sub menu Data Master pilih Input data lahan. Adapun tampilan sub menu Data Master Input data lahan seperti gambar 4 dibawah ini

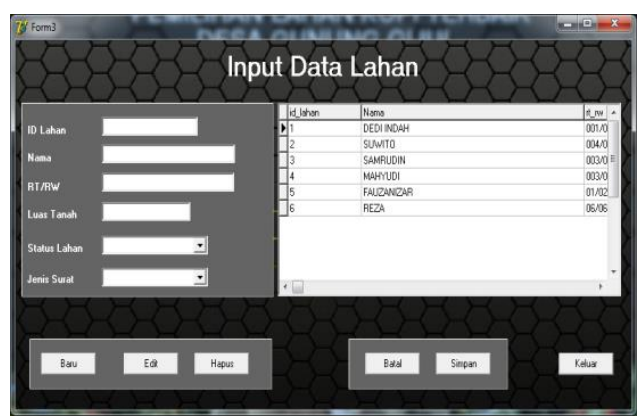

Gambar 4 Data Lahan

\subsection{Menu Data Nilai Lahan}

Untuk menjalankan sub menu Data Master ini, terlebih dahulu pemakai masuk kedalam menu utama program lalu pada sub menu Data Master pilih Input data Nilai lahan. Adapun tampilan sub menu Data Master Input data Nilai lahan seperti gambar 5 dibawah ini

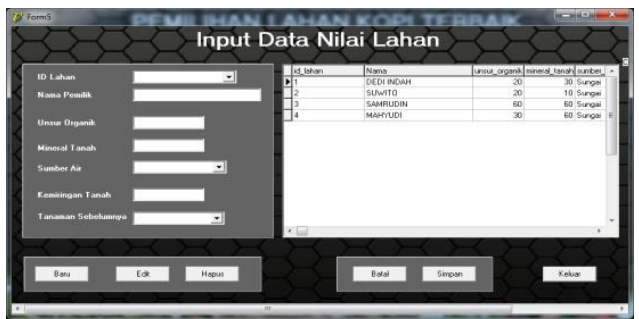

Gambar 5 Data Nilai Lahan

\subsection{Menu Set AHP}

Untuk menjalankan sub menu Penilaian ini, terlebih dahulu pemakai masuk kedalam menu utama program lalu pada sub menu Penilaian pilih Set AHP. Adapun tampilan sub menu Set AHP seperti gambar 6 dibawah ini

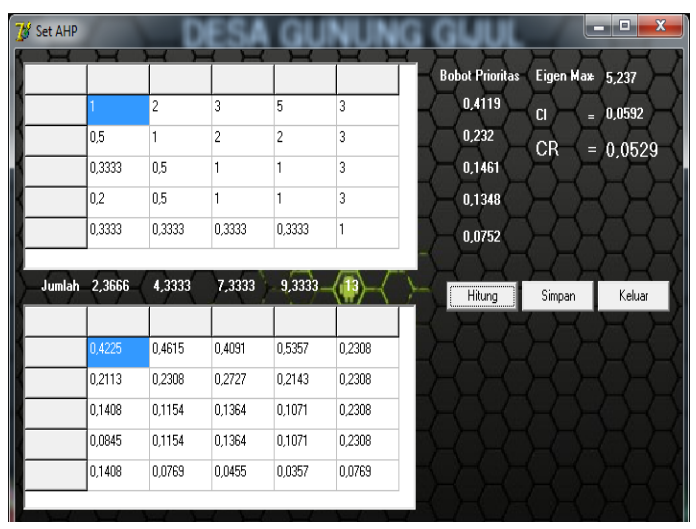

Gambar 6 Set AHP

\subsection{Menu Penilaian AHP}

Untuk menjalankan sub menu Penilaian ini, terlebih dahulu pemakai masuk kedalam menu utama program lalu pada sub menu Penilaian pilih Penilaian AHP. Adapun tampilan sub menu Penilaian AHP seperti gambar 7 dibawah ini :

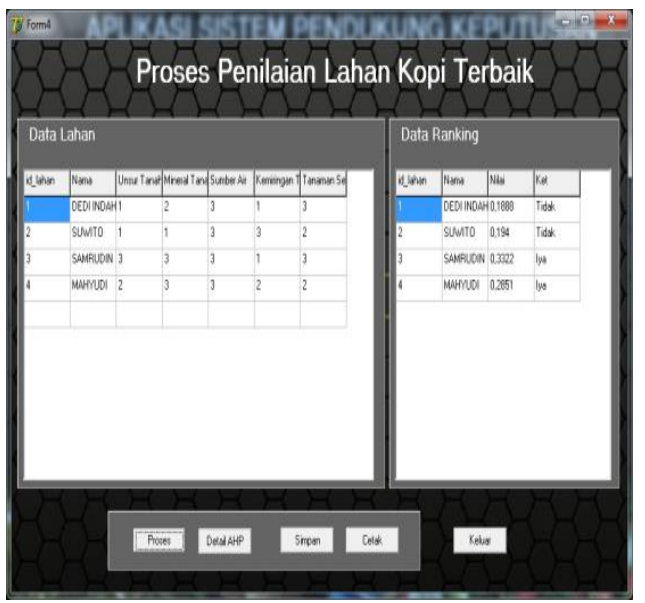

Gambar 7 Peilaian AHP 


\subsection{Detail AHP}

Untuk menjalankan form detail AHP ini, terlebih dahulu pemakai masuk kedalam menu Penilaian AHP lalu klik pada tombol detail AHP. Adapun tampilan form detail AHP seperti gambar 8 dibawah ini :

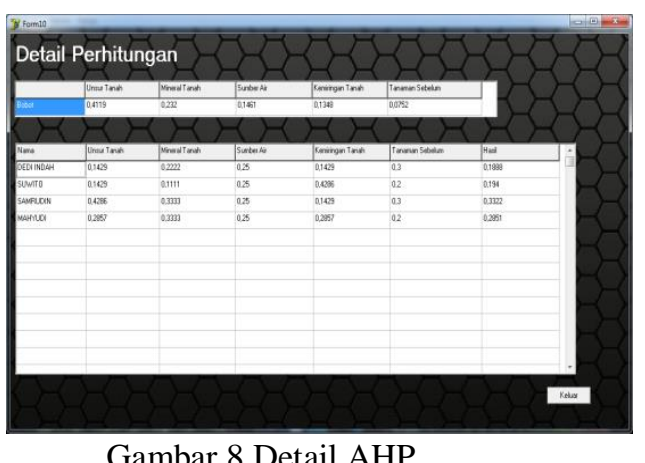

Gambar 8 Detail AHP

\subsection{Laporan Hasil Lahan Kopi Terbaik}

Untuk menjalankan menu laporan ini terlebih dahulu pemakai masuk kedalam Menu utama Program lalu pada sub menu laporan, pilih laporan lahan kopi terbaik. Adapun tampilan sub menu laporan Lahan Kopi Terbaik seperti gambar 9 dibawah ini :

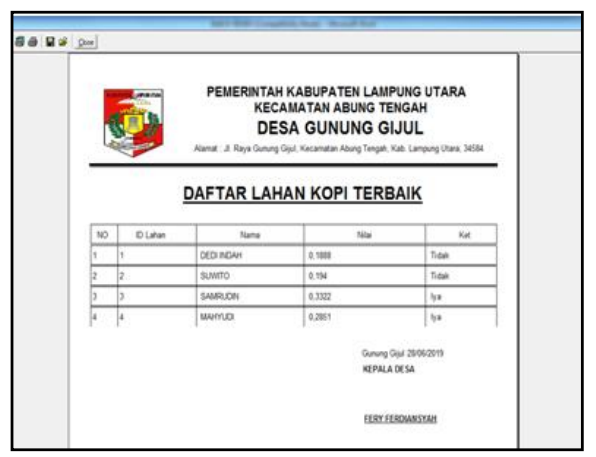

Gambar 9 Hasil Lahan Kopi Terbaik

\section{PENUTUP}

\subsection{Kesimpulan}

Kesimpulan penulis terhadap Sistem Pendukung Keputusan peentuan lahan kopi terbaik pada desa gunung gijul Dengan Menggunakan Metode Analytic Hierarchy Process, dapat diambil beberapa kesimpulan yaitu sebagai berikut :

1. Penentuan lahan kopi terbaik menggunakan metode AHP (Analytic Hierarchy Process) dapat diterapkan dan menghasilkan nilai yang dirasa cukup tepat.

2. Diharapkan dengan dirancangnya Sistem Pendukung Keputusan Penentuan lahan kopi terbaik dengan menggunakan metode AHP (Analytic Hierarchy Process) berbasis Borland Delphi 7 ini menghasilkan informasi lahan kopi terbaik.

3. Keputusan sistem dinyatakan telah sesuai dengan kriteria pemilihan lahan kopi terbaik pada Desa Gunung Gijul sehingga dapat dijadikan acuan oleh pihak Desa Gunung Gijul.

\subsection{Saran}

Berdasarkan hasil penelitian diatas, maka penulis memberikan saran pada Aplikasi Sistem Pendukung Keputusan penentuan lahan kopi terbaik sebagai berikut:

1. Sistem ini masih terbatas maka perlu ditambahkan dan dikembangkan fungsi untuk menambahkan kriteria penentuan lahan kopi terbaik.

2. Penelitian selanjutnya pengembangan sistem dapat dikembangkan menggunakan metode lain, sehingga bisa menjadi pembanding untuk tingkat ketepatan dalam pemilihan lahan kopi terbaik.

\section{DAFTAR PUSTAKA}

[1] Adikara R Moh Andriawan. Sistem Pendukung Keputusan Pemilihan Varietas Unggul Jagung Hibrida Menggunakan Metode AHP-SMART. Jurnal Pengembangan Teknologi Informasi dan Ilmu Komputer. Fakultas Ilmu Komputer, Universitas Brawijaya. (2018)

[2] Fazliani, Widians Joan Angelina Dan Islamiyah.Sistem Pendukung Keputusan Pemilihan Jenis Bibit Unggul Kelapa Sawit Dengan Metode Analytic Hierarchy Process (AHP). Prosiding Seminar Ilmu Komputer dan Teknologi Informasi Vol. 2, No. 1. (2017)

[3] Mohamad Haryadi. Pengamanan File Teks Dengan Teknik Enkripsi Vigeneree Menggunakan Delphi XE2.Sekolah Tinggi Manajemen Informatika Dan Ilmu Komputer Elrahma.Yogyakarta. (2016)

[4] Hatta Heliza Rahmania,dkk. Pemilihan Lahan Terbaik Untuk Tanaman Kelapa 
Sawit Menggunakan Metode Simple Additive Weighting. Seminar Nasional Inovasi Dan Aplikasi Teknologi Di Industri 2017. Fakultas Ilmu Komputer Dan Teknologi Informasi, Universitas Mulawarman. (2017)

[5] I Wayan Supriana.Perancangan Sistem Pendukung Keputusan Dalam Penentuan Penggunaan Pupuk Kimia Pada Tanaman Jagung Dengan Metode AHP.Program Studi Teknik Informatika.Fakultas Ilmu Kesehatan Sains Dan Teknologi Universitas Dhayana Pura Bali. (2016)

[6] Munthe, G. Q., Penerapan Metode Analytical Hierarchy Process (AHP) Dalam Menentukan Prioritas Pengembangan Infrastruktur Kota Medan. Skripsi S1, Universitas Sumatera Utara.Medan. (2016) 